\title{
Occupational and Environmental Health Hazards (Physical \& Mental) Among Rag-Pickers in Mumbai Slums: A Cross-Sectional Study
}

\author{
Balu Natha Mote', Suhas Balasaheb Kadam ${ }^{2}$, , Shrikant Kishorrao Kalaskar ${ }^{3}$, \\ Bharat Shivajirao Thakare ${ }^{4}$, Ambadas Suresh Adhav ${ }^{4}$, Thirumugam Muthuvel ${ }^{5}$ \\ ${ }^{1}$ Foundation for Research in Community Health (FRCH), Pune, India \\ ${ }^{2}$ Department of Research \& Documentation, State Health Systems Resource Centre, Maharashtra, India \\ ${ }^{3}$ National Institute of Health and Family Welfare (NIHFW), New Delhi, India \\ ${ }^{4}$ Meditation, AIDS, Health, De-Addiction, Nutrition (MAHAN), Melghat, India \\ ${ }^{5}$ Independent Researcher, Chennai, India
}

\section{Email address:}

mote.balu84@gmail.com (B. N. Mote),drsuhas.tiss@gmail.com (S. B. Kadam), skkalaskar1987@gmail.com (S. K. Kalaskar), bharat.thakare9206@gmail.com (B. S. Thakare), adhavambadas@gmail.com (A. S. Adhav), thirumugam@gmail.com (T. Muthuvel)

\section{To cite this article:}

Balu Natha Mote, Suhas Balasaheb Kadam, Shrikant Kishorrao Kalaskar, Bharat Shivajirao Thakare, Ambadas Suresh Adhav, Thirumugam Muthuvel. Occupational and Environmental Health Hazards (Physical \& Mental) Among Rag-Pickers in Mumbai Slums: A Cross-Sectional Study. Science Journal of Public Health. Vol. 4, No. 1, 2016, pp. 1-10. doi: 10.11648/j.sjph.20160401.11

\begin{abstract}
Rag pickers are informal workers who collect recyclable materials to earn a small wage on daily basis. Their life and working conditions are extremely difficult. This paper examined the health status, occupational and environmental health hazards among rag-pickers working in dumping ground of Shivaji-Nagar and Govandi Slums of Mumbai, India. The crosssectional study gathered data by interviewing 120 rag pickers during the Masters in Public Health course curriculum at Tata Institute of Social Sciences (TISS) in the year 2012-13. The Occupational and environmental health (Physical \& Mental) hazards were assessed using a standard self-reporting questionnaire. Convenient sampling was used to select the rag pickers from the slums of Mumbai. The study shows, rag-pickers suffer from physical as well as mental ill health. The reason for engaged in such kind of work is due to not having other skills and easy or daily income. Most of them are having habits such as tobacco-chewing and consumption. Dog bite and rat bite are common among Rag-pickers. Redness of eyes, headache, backache, accidental injuries are very common among Rag-pickers. Substance abuse itself is one of the mental disorders present among Rag-pickers. Majority of them are associated with mild depression and mild anxiety as common mental disorders. Rag pickers more frequently report physical and mental health problems. Improving the work lives of these precarious workers should address not only the physical hazards of their jobs but their mental and emotional health as well. Unfulfilled health needs of this underprivileged workforce who contributes to the ecology and economy of the city need to be addressed. Sensitization of both general public and government workforce is essential to legitimize this occupation. This in turn may help to alleviate poverty and environmental degradation which is occurring due to rapid and unplanned urbanization in India.
\end{abstract}

Keywords: Rag Pickers, Slums, Mumbai, India, Environmental and Occupational Health Hazards,

Physical \& Mental Health Hazards

\section{Introduction}

Today, more than half population of world lives in cities and by 2030 developing countries will account for the 80 percentage world's urban population. In urban India more than 60 millions of people live in urban slum and such population account for more than 20 percentage of total urban population. There is scarcity of housing, watersanitation, health care providers and education.

Globally, rapid and unplanned urbanization is the trend for most of the developing countries including India. Worldwide there is a huge outcry about its impact on the rapidly exhausting scarce resources for development. Although the 
same is echoed in India, not enough attention has been paid on the crucial linkage between the crippling waste disposal system; a byproduct of the population explosion and degradation of both environmental as well as human health [1].

Waste is an unavoidable by-product of human activities. Economic development, urbanization and improved living standards in cities contribute to increase in the quantity and complexity of generated solid waste. If accumulated, it leads to degradation of urban environment, stresses natural resources and leads to health problems. Solid waste management has become a major environmental issue in India. Waste management, however, remains a major challenge for any society, since all natural processes generate waste. Collection of solid waste and disposing it is the supplemented by waste pickers, more commonly known as rag pickers. They are at the base of the hierarchy of collection and disposal of waste [2]. Rag pickers play an important, but usually unrecognized role in the waste management system of Indian cities. They collect garbage in search of recyclable items that can be sold to scrap merchant like paper, plastic, tin... etc. This activity requires no skills and is a source of income for a growing number of urban poor people.

Migration is one of the crucial problems for increasing the slum of Mumbai. Shivaji-Nagar is area which is mostly cover by Muslim population. Most of people residing around the area of dumping ground are migrants from Uttar-Pradesh, Bihar, Bangladesh and from within Maharashtra such as Aurangabad, Jalna, Nanded etc. Most of the waste dumping sites are extremely unhygienic. The rotten waste becomes breeding spot for germs. Rag pickers collect solid waste from such unhygienic sites. They need to roam through mounds of rotten, unhygienic and germ rich sites. They pick diseases (mostly infectious) along with waste. Rag pickers are very poor and live in nearby the dumping station. They have poor quality of houses without running water or electricity facilities. They are dependent on hand pump water. The dumping grounds leads to deterioration of water quality in surrounding areas and contaminate the water. This adds on to the poor health conditions of rag pickers [3].

Poor people come from various state of India to Mumbai for their daily bread and butter and start living in slum which is mostly not organized and here start the problem of their poor health condition. Migrant who mostly are uneducated and not having any skill for doing any good type of work start working in bad type of occupation like waste-worker, and other minimal type of work. So in this way poverty, migration, less education, religion, income becomes the predisposing factor for their bad health condition. Illiteracy, poverty, indebtedness and migration of their family are the main causes for the poor working condition for rag picking activity, which has become one of the important social problems. Directly enrolment in Rag-picking is due to noneligibility for other works which require skills and also because of the easy daily income.

Rag-picking, waste working and scavengers are Indian term used for the minimal type of working for recycling the waste. Rag-pickers are always living in high risk area as they spend average 8-10 hours in dumping ground which is nothing but source of various type of common illness. Such kinds of work generate various substance abuse practices among the Rag-pickers. This paper describes the socioeconomic profile with occupational health risks to which rag pickers are exposed in their work and to study the morbidity pattern and mental health issue among the rag pickers.

Rag picking is probably one of the most dangerous and dehumanizing activity in India. Rag pickers are working in filthy environments, surrounded by crows or dogs under any weather conditions and have to search through hazardous waste without gloves or shoes. They often eat the filthy food remnants they find in the garbage bins or in the dumping ground. Using the dumping ground as a playing field the children run the risk to come upon needles, syringes, used condoms, saline bottles, soiled gloves and other hospital wastes as well as ample of plastic and iron items. They suffer from many diseases, such as respiratory problems, worms, anaemia, fever and other problems which include cuts, rashes, dog bites [4].

The paper makes use of a database, parenting to the socioeconomic profile of the rag pickers including the working conditions, and their problems and expectations. This information has been developed through literature review, questionnaire survey and open-ended interviews conducted to generate data on rag pickers. This paper reviews the already existing database on rag pickers and explains the morbidity due to common illnesses, common mental illnesses and health seeking behaviour among rag pickers in Slums of Mumbai.

\section{Objectives of the Study}

\subsection{Broad Objective}

To study the physical and mental health issue among Ragpickers

\subsection{Specific Objective}

(1) To study the morbidity due to common illnesses among Rag-pickers.

(2) To study the common mental illness (depression \& anxiety) among Rag-pickers.

(3) To study the health seeking behavior of Rag-pickers.

\subsection{Research Question}

(1) What are the different common illnesses present among Rag-pickers?

(2) What are the different substance use practices among Rag-pickers?

(3) Is there any specific health impact on women health due to Rag-picking?

(4) What are the common mental disorders among Ragpickers?

(5) What is the pattern of health seeking behavior of Rag-pickers? 
(6) What are different types of injury common among Rag-pickers during their work time?

(7) What is income level among Rag-pickers?

(8) What is gross expenditure on health care?

\section{Methodology}

\subsection{Study Population}

Study population is around the area of dumping ground, Rag-pickers are chosen from the Indira nagar, Padma nagar, Shanti nagar and Rafi nagar.

\subsection{Sampling Procedure}

For study 120 Rag-pickers are chosen from various part of belt of dumping ground such as Indira nagar, Padma nagar, Shanti nagar and Rafi nagar. Convenient sampling was used to select the sample. Males and females above the age of 18 were selected for the interview.

\subsection{Exclusion Criteria}

Children below the age 18 are excluded from the study due to ethical consideration problem and consent issue as parents of such kind of children are not available for the consent on study time.

\subsection{Study Method}

A cross sectional quantitative study was done. Data was collected using structured questionnaire using a face to face interview. Rag-pickers were used as key informants to get information about other rag pickers.

\subsection{Data Analysis}

Data collected was analysed using SPSS and MS Excel and presented in tabular and graphical format in the observations section.

\section{Observations}

The findings of the study are explained below.

\subsection{Age Wise Distribution of the Rag Pickers}

Table 1. Age wise distribution of the rag pickers.

\begin{tabular}{lll}
\hline Age categories & Frequency & Percent \\
\hline $15-25$ & 25 & 20.8 \\
$25-35$ & 39 & 32.5 \\
$35-50$ & 42 & 35.0 \\
$50-60$ & 6 & 5.0 \\
Greater than 60 & 8 & 6.7 \\
Total & 120 & 100.0 \\
\hline
\end{tabular}

Table no. 1 shows that most of the rag pickers (nearly $50 \%$ ) are 15-35 age groups, which is the young population of the area. This also shows the alarming situation that, the youths are engaged in the rag picking occupation rather than educating them. The National Urban Livelihood Mission, NULM.

\subsection{Gender and Religion}

Table 2. Gender and Religion Cross-tabulation.

\begin{tabular}{llllllll}
\hline & & \multicolumn{2}{l}{ Religion, N (\%) } & & & \\
\cline { 2 - 8 } & Muslim & Hindu & Christian & Buddhist & Telagu & Total \\
\hline \multirow{2}{*}{ Gender } & Male & $42(71.2 \%)$ & $8(13.6 \%)$ & $2(3.4 \%)$ & $7(11.9 \%)$ & $0(0.0 \%)$ & $59(100.0 \%)$ \\
& Female & $36(59.0 \%)$ & $11(18.0 \%)$ & $0(0.0 \%)$ & $13(21.3 \%)$ & $1(1.6 \%)$ & $61(100.0 \%)$ \\
& Total & $78(65.0 \%)$ & $19(15.8 \%)$ & $2(1.7 \%)$ & $20(16.7 \%)$ & $1(0.8 \%)$ & $120(100.0 \%)$ \\
\hline
\end{tabular}

The table no. 2 above shows gender and religion cross tabulation. Among the rag pickers included in the study, most were Muslim (65\%), subsequently Buddhist (16.7\%) and Hindu (15.8\%). It also shows that the percentage of males and females is almost equal.

\subsection{Sub-caste Wise Distribution of Rag Pickers}

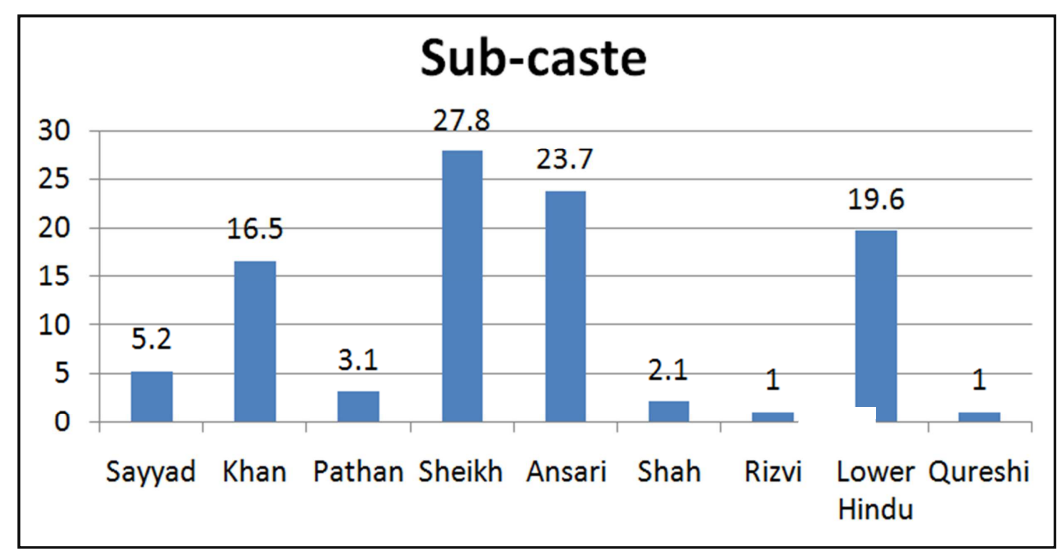

Figure 1. Sub-caste wise distribution of rag pickers. 
The figure 1 above shows among Muslims Sheikh and Ansari has the highest number of rag-pickers.

\subsection{Background Characteristics}

Table 3. Background characteristics.

\begin{tabular}{|c|c|c|c|}
\hline Background characteristics & Categories & Frequency $(n=120)$ & Percentage \\
\hline \multirow{4}{*}{ Education } & Illiterate & 85 & 70.8 \\
\hline & Primary education & 12 & 10.0 \\
\hline & Secondary education & 23 & 19.2 \\
\hline & Total & 120 & 100.0 \\
\hline \multirow{4}{*}{ Marital status } & Married & 95 & 79.2 \\
\hline & Divorced & 5 & 4.2 \\
\hline & Widow & 12 & 10.0 \\
\hline & Unmarried & 8 & 6.7 \\
\hline \multirow{5}{*}{ Engaged in occupation since } & Below 5 year & 20 & 16.7 \\
\hline & 6 to 10 year & 39 & 32.5 \\
\hline & 11 to 15 year & 25 & 20.8 \\
\hline & 16 to 20 year & 20 & 16.7 \\
\hline & Above 20 year & 16 & 13.3 \\
\hline \multirow{4}{*}{ Working time in occupation } & below 6 hours & 26 & 21.7 \\
\hline & 7 to 8 hours & 37 & 30.8 \\
\hline & 9 to 12 hours & 55 & 45.8 \\
\hline & above 12 hours & 2 & 1.7 \\
\hline \multirow{6}{*}{ Per month expenditure on treatment } & less than Rs. 250 & 10 & 8.3 \\
\hline & Rs. 251 to 500 & 41 & 34.2 \\
\hline & Rs. 501 to 1000 & 53 & 44.2 \\
\hline & Rs. 1001 to 1500 & 12 & 10.0 \\
\hline & Rs. 1501 to 3000 & 3 & 2.5 \\
\hline & Rs. 3001 to 5000 & 1 & .8 \\
\hline \multirow{5}{*}{ Reason for choosing such work? } & NO OTHER SKILL & 61 & 50.8 \\
\hline & DAILY INCOME & 4 & 3.3 \\
\hline & EASY INCOME & 13 & 10.8 \\
\hline & NO EDUCATION & 14 & 11.7 \\
\hline & both easy income and no other work eligibility & 28 & 23.3 \\
\hline
\end{tabular}

The out of pocket expenditure on various items was found in most cases around Rs. 501 to 1000/- per month. The reason for engaged in such kind of work is due to not having other skill and easy or daily income. The engagement duration in ragpicking for majority of them is 5 to 10 years.

\subsection{Discrimination Among Rag-Pickers}

Table 4. Discrimination among rag-pickers.

\begin{tabular}{|c|c|c|c|}
\hline Discrimination among rag-pickers: & Categories & Frequency $(n=120)$ & Percentage \\
\hline \multirow{3}{*}{$\begin{array}{l}\text { Do you feel discrimination by society because of your } \\
\text { work? }\end{array}$} & YES & 33 & 27.5 \\
\hline & NO & 87 & 72.5 \\
\hline & due to dirty work & 18 & 15.0 \\
\hline \multirow[t]{5}{*}{ What do you think might be the cause of discrimination? } & unhygienic condition & 15 & 12.5 \\
\hline & Don’t know & 87 & 72.5 \\
\hline & By police & 24 & 20.0 \\
\hline & By local gunda & 8 & 6.7 \\
\hline & Female eve teasing & 17 & 14.2 \\
\hline \multirow{7}{*}{ What problems do you face at the working site? } & Uncertainty of job & 15 & 12.5 \\
\hline & Katewala corruption & 3 & 2.5 \\
\hline & All of them & 27 & 22.5 \\
\hline & None of them & 26 & 21.7 \\
\hline & Intra-state migration & 40 & 33.3 \\
\hline & from north India (Uttar Pradesh) & 39 & 32.5 \\
\hline & from north India ( Bihar) & 20 & 16.7 \\
\hline \multirow[t]{5}{*}{ Migration of rag-pickers } & from south India & 12 & 10.0 \\
\hline & migration from neighbouring country & 3 & 2.5 \\
\hline & from north-east India & 1 & .8 \\
\hline & no migrant & 5 & 4.2 \\
\hline & very dirty & 1 & .8 \\
\hline \multirow{3}{*}{$\begin{array}{l}\text { Working environment of rag-pickers? (based on researcher's } \\
\text { observation) }\end{array}$} & average dirty & 45 & 37.5 \\
\hline & dirty & 47 & 39.2 \\
\hline & no dirty & 27 & 22.5 \\
\hline
\end{tabular}


Mostly Rag-pickers populations are Migrant and stay here in Mumbai from last 5-10 years. Maximum numbers of Ragpickers are Migrant from Uttar-Pradesh, Bihar, Nepal, and Bangladesh. $28 \%$ of the rag pickers feel discrimination by society because of their work.

Working environment of rag-pickers (based on researcher's observation):

1) VERY DIRTY: if he works in wet and dry waste without shirt and his body is wrapped with mud. Such type of worker is usually found working in gutter for cleaning the blockage of gutter in rainy season.

2) AVERAGE DIRTY: if he works in dry waste without any protective cloth.

3) DIRTY: if he works in dry waste with some protective cloth.

\subsection{Health Status of Rag-Pickers}

Table 5. Health status of rag-pickers.

\begin{tabular}{|c|c|c|c|}
\hline Health condition & Categories & Frequency $(n=120)$ & Percentage \\
\hline \multirow{2}{*}{ Injury during work } & Yes & 110 & 91.7 \\
\hline & No & 10 & 8.3 \\
\hline \multirow{5}{*}{ Type of injury during work } & Cut and Pinprick & 87 & 72.5 \\
\hline & Only cut & 20 & 16.7 \\
\hline & Only pinprick & 3 & 2.5 \\
\hline & Accidental & 3 & 2.5 \\
\hline & Not known & 7 & 5.8 \\
\hline \multirow{6}{*}{ Substance causing injury } & glass and metal & 88 & 73.3 \\
\hline & only glass & 17 & 14.2 \\
\hline & only pinprick & 3 & 2.5 \\
\hline & stone & 1 & .8 \\
\hline & all of them & 4 & 3.3 \\
\hline & Not known & 7 & 5.8 \\
\hline \multirow{4}{*}{ Muscular pain } & Body ache & 30 & 25.0 \\
\hline & Joint pain & 6 & 5.0 \\
\hline & Backache & 48 & 40.0 \\
\hline & No pain & 36 & 30.0 \\
\hline \multirow{5}{*}{ Animal bite at working site } & Dog & 17 & 14.2 \\
\hline & Rat & 23 & 19.2 \\
\hline & Others & 2 & 1.7 \\
\hline & Snake bite & 3 & 2.5 \\
\hline & No bite & 75 & 62.5 \\
\hline \multirow{3}{*}{ General illness episodes in last month } & Yes & 86 & 71.7 \\
\hline & No & 33 & 27.5 \\
\hline & Not known & 1 & .8 \\
\hline \multirow{6}{*}{ Headache episodes in last month } & 1 to 4 time & 48 & 40.0 \\
\hline & 5 to 8 time & 18 & 15.0 \\
\hline & 9 to 12 time & 16 & 13.3 \\
\hline & 13 to 15 time & 9 & 7.5 \\
\hline & 16 to 30 time & 5 & 4.2 \\
\hline & No & 24 & 20.0 \\
\hline \multirow{5}{*}{ Problems related to eye } & Redness & 26 & 21.7 \\
\hline & Soreness & 34 & 28.3 \\
\hline & Watering & 4 & 3.3 \\
\hline & Swelling & 4 & 3.3 \\
\hline & No & 52 & 43.3 \\
\hline \multirow{4}{*}{ Redness of eyes } & Mild & 40 & 33.3 \\
\hline & Moderate & 20 & 16.7 \\
\hline & Severe & 7 & 5.8 \\
\hline & No & 53 & 44.2 \\
\hline \multirow{4}{*}{ Watering of eyes } & Mild & 4 & 3.3 \\
\hline & Moderate & 4 & 3.3 \\
\hline & Severe & 7 & 5.8 \\
\hline & No & 105 & 87.5 \\
\hline \multirow{3}{*}{ Common cold episodes } & Common cold & 38 & 31.7 \\
\hline & Fever & 8 & 6.7 \\
\hline & No illness & 74 & 61.7 \\
\hline
\end{tabular}




\begin{tabular}{|c|c|c|c|}
\hline Health condition & Categories & Frequency $(n=120)$ & Percentage \\
\hline \multirow{3}{*}{ Respiratory illness } & Yes & 61 & 50.8 \\
\hline & No & 58 & 48.3 \\
\hline & Don't know & 1 & .8 \\
\hline \multirow{4}{*}{ Breathlessness episodes } & 1 to 4 & 45 & 37.5 \\
\hline & 4 to 10 & 14 & 11.7 \\
\hline & 11 to 15 & 2 & 1.7 \\
\hline & No & 59 & 49.2 \\
\hline \multirow{2}{*}{ Skin diseases episodes } & Yes & 20 & 16.7 \\
\hline & No & 100 & 83.3 \\
\hline \multirow{6}{*}{ Infectious diseases } & Malaria & 14 & 11.7 \\
\hline & Typhoid & 6 & 5.0 \\
\hline & Dysentery & 11 & 9.2 \\
\hline & Jaundice & 7 & 5.8 \\
\hline & Viral fever & 16 & 13.3 \\
\hline & No & 66 & 55.0 \\
\hline \multirow{2}{*}{ Tuberculosis diseases - self reported } & yes & 20 & 16.7 \\
\hline & no & 100 & 83.3 \\
\hline \multirow{4}{*}{ Cardio-vascular illness - self reported } & HTN & 16 & 13.3 \\
\hline & LOW BP & 8 & 6.7 \\
\hline & IHD & 3 & 2.5 \\
\hline & No & 93 & 77.5 \\
\hline \multirow{4}{*}{$\begin{array}{l}\text { Do you feel any mental health disorder } \\
\text { (depression)? }\end{array}$} & Mild depression & 58 & 48.3 \\
\hline & Moderate depression & 12 & 10.0 \\
\hline & Moderate to severe depression & 2 & 1.7 \\
\hline & No depression & 48 & 40.0 \\
\hline \multirow{4}{*}{ Do you feel any mental health disorder (anxiety)? } & Mild anxiety & 56 & 46.7 \\
\hline & Moderate anxiety & 6 & 5.0 \\
\hline & Severe anxiety & 4 & 3.3 \\
\hline & No anxiety & 54 & 45.0 \\
\hline \multirow{2}{*}{ General look of teeth } & Stain present & 80 & 66.7 \\
\hline & stain absent & 40 & 33.3 \\
\hline \multirow{2}{*}{ Signs and symptoms of gingivitis? } & Gingivitis present & 38 & 31.7 \\
\hline & Gingivitis absent & 82 & 68.3 \\
\hline
\end{tabular}

As Rag-pickers working in dumping ground I am surprised to see very few percentage of them are affected by skin diseases. Actually while doing community survey we found that people of the community baths every alternate day. Most of them are found to be affected with scabies, but in case of Rag-pickers as they found to bathing practices every day they are less affected with scabies as a skin diseases, they are affected with skin chemical burn, sun burn while doing work on dumping ground.

Cut \& pinprick injury are common among Rag-pickers. Both glass \& metal are common as injury causing substance among Rag-pickers. Very few Rag-pickers are found of under gone cataract surgery. Upon asking about their oral health as they are having more substance abuse practices such as tobacco chewing, pan chewing etc. then it was found that female are having little high practices of chewing pan etc. so they also have little high gingivitis among them.

In case of stain present or absent fallowing graph show that male are having little high percentage of stain than female as male are having high substance use practices such as tobacco, pan, gutkha than female. Dog bite and rat bite are common among Rag-pickers. 65\% percentage of Rag-pickers population is illiterate. $22 \%$ of Rag-pickers population is completed education up to $5^{\text {th }}$ standard.
Redness of eyes, headache, backache, accidental injury is very common among Rag-pickers. Prevalence of Tuberculosis is found to be little high among Rag-pickers than prevalence of $\mathrm{T}$. B. of national level. In the study male Rag-pickers are found to be more affected by T. B. than female.

Mental morbidity (depression \& anxiety) among ragpickers: Substance abuse itself is one of the mental disorders present among Rag-pickers. Various type of smokeless and other tobacco practices are common among rag-pickers. Ragpickers also show the withdrawal symptom of substance abuse practices which show the dependency of Rag-pickers on tobacco. It was found that alcohol drinking among Ragpickers is quite low among rag pickers belong to the Muslim religion. Rag-pickers are always in fear of loss of job from Rag-picking as they hear news of closing of dumping ground in next few months and are always harassed by local gunda.

Study found that mental disorder such as mild depression and mild anxiety is common among Rag-pickers. Female Rag-pickers are showing high percentage of mild depression and mild anxiety than Male Rag-pickers. Very few cases of moderate depression and moderate anxiety were found. 1 or 2 percentage of severe anxiety and depression were found, after probing further about cause of respective Rag-pickers 
for such kind of condition, I was found that they have some serious problem in their house such death of family member, accident of family member etc. So in this way household condition as well as occupational condition fall them (Ragpickers) into such kind of common mental disorders.

Majority of them are associated with mild depression and mild anxiety as common mental disorder. Female Ragpickers show high number of mild depression and mild anxiety than male Rag-pickers. Maximum numbers of Ragpickers prefer private G. P. and BMC for their treatment. Rag pickers more frequently report MPD (Minor psychiatric disorders) than other poor workers living in the same neighborhoods, with many of the same life conditions. MPD were more common among females, those of lower economic level, smokers and alcoholics. Among occupational characteristics, MPD prevalence was associated with frequent static postures, low job satisfaction and recent work accidents. Informal workers, especially rag pickers, have lower status than formal workers, lack security of employment and have less control over their working conditions [5].

In Mumbai, a study revealed that the respondents of the slums which does not have proper basic facilities like water, toilet, electricity, drainage as it does not come under the jurisdiction of BMC, lack congenial environment for health. The dumping ground nearby is the main cause of poor health in this area [6]. Same findings found in this study.

Psychosocial hazards result from the long and irregular workdays of this population, often including night work. In addition, the daily struggle for survival, the uncertainty about the future, the lack of prospects for a better life, low wages, and job discrimination all can have negative impacts on their mental health [7-11]. The rag pickers showed a higher prevalence of low hemoglobin, high circulating eosinophil and monocyte counts, unhealthy gums, frequent diarrhea, and dermatitis. They have poor health conditions than others. They suffer from physical illnesses such as injuries and infectious illnesses including diarrhea, malaria, pneumonia etc [7-11]. These findings also correlate with the findings of this study, regarding mental health and other health issues.

Common health problems: Most common health problem reported by the respondents were respiratory disorders, followed by cold, cough, fever, skin and gastro-intestinal infection. Cases of tuberculosis and hypertension were also found. Health seeking behavior: Most of the respondents $(86 \%)$ availed allopathic treatment when they were ill. One of the main reasons for this is that most of the general practitioners in this area, despite holding various degrees for example, Ayurvedic and Homeopathy, dispense allopathic medicine [6].

\subsection{Smoking / Drinking Habits}

Table 6. Smoking / drinking habits.

\begin{tabular}{|c|c|c|c|}
\hline Health condition & Categories & Frequency $(n=120)$ & Percentage \\
\hline \multirow{2}{*}{ Have you used any substance (tobacco, alcohol etc.) in last week? } & Yes & 98 & 81.7 \\
\hline & No & 22 & 18.3 \\
\hline \multirow{6}{*}{ Do you use smoke form of tobacco? } & Beedi & 12 & 10.0 \\
\hline & Cigar rate & 14 & 11.7 \\
\hline & Ganja & 2 & 1.7 \\
\hline & Others & 9 & 7.5 \\
\hline & No & 81 & 67.5 \\
\hline & Did not respond & 2 & 1.7 \\
\hline \multirow{11}{*}{ Have you ever felt withdrawal symptoms, if tried to stop substances? } & Headache & 7 & 5.8 \\
\hline & Lingering & 1 & .8 \\
\hline & Tremor & 3 & 2.5 \\
\hline & Restlessness & 25 & 20.8 \\
\hline & Lethargic & 5 & 4.2 \\
\hline & Anxiety & 13 & 10.8 \\
\hline & Depression & 1 & .8 \\
\hline & Others & 1 & .8 \\
\hline & No & 27 & 22.5 \\
\hline & Crave & 33 & 27.5 \\
\hline & Don't know & 4 & 3.3 \\
\hline \multirow{3}{*}{ Do you drink alcohol? } & Yes & 11 & 9.2 \\
\hline & No & 108 & 90.0 \\
\hline & Did not respond & 1 & .8 \\
\hline
\end{tabular}

Various types of substance abuse practices are common among Rag-pickers. Alcohol consumption is found to be very low among Rag-pickers. Illiterate, school dropout rate is high because of no interest and responsibility of house hold for livelihood. 


\subsection{Awareness About HIV}

Table 7. Awareness about HIV.

\begin{tabular}{llll}
\hline Awareness about HIV & Categories & Frequencies & Percentage \\
\hline \multirow{2}{*}{ Did you hear about HIV-AIDS? } & Yes & 50 & 41.7 \\
& No & 70 & 58.3 \\
Did you undergo HIV-testing in past? if yes, then result? & Positive & 4 & 3.3 \\
& Negative & 40 & 33.3 \\
\hline
\end{tabular}

Nearly $60 \%$ of the rag pickers did not hear about HIV-AIDS.

\subsection{Precautionary Behaviour}

Table 8. Precautionary behavior.

\begin{tabular}{|c|c|c|c|}
\hline Precautionary behaviour & Categories & Frequencies & Percentage \\
\hline \multirow{2}{*}{ Any precautionary behaviour is you following? } & Yes & 49 & 40.8 \\
\hline & No & 71 & 59.2 \\
\hline \multirow{3}{*}{ Medium of precaution used? } & Hook & 48 & 40.0 \\
\hline & Plastic bag & 10 & 8.3 \\
\hline & No & 62 & 51.7 \\
\hline Do you use any protective clothes while doing work? & Yes & 83 & 69.2 \\
\hline
\end{tabular}

60 percent of the rag pickers follow precautionary behaviour regarding rag picking by means of various mediums.

\subsection{Health Seeking Behaviour}

Table 9. Health seeking behavior.

\begin{tabular}{|c|c|c|c|}
\hline Indicator & Categories & Frequencies & Percentage \\
\hline \multirow{2}{*}{ Have you attended any health check-up camp? } & Yes & 30 & 25.0 \\
\hline & No & 90 & 75.0 \\
\hline \multirow{4}{*}{ What is your choice of treatment facility? } & Home remedy & 2 & 1.7 \\
\hline & Pvt GP & 54 & 45.0 \\
\hline & BMC & 26 & 21.7 \\
\hline & First GP then BMC & 34 & 28.3 \\
\hline
\end{tabular}

75 percent of the rag pickers have not attended any health check-up camp for regular health check-ups. Most preferred choice of treatment facility was a private general practitioner for every health problem they face.

\section{Discussion}

The study shows, rag-pickers suffer from physical as well as mental ill health. The reason for engaged in such kind of work is due to not having other skill and easy or daily income. Most of them are having habits such as tobacco-chewing and consumption. Dog bite and rat bite are common among Ragpickers. Redness of eyes, headache, backache, accidental injury is very common among Rag-pickers. Substance abuse itself is one of the mental disorders present among Ragpickers. Study found that mental disorder such as mild depression and mild anxiety is common among Rag-pickers. Majority of them are associated with mild depression and mild anxiety as common mental disorder. The out of pocket expenditure on various items was found in most cases around Rs. 501 to $1000 /-$.
Hazards faced by rag pickers: [7]

Ergonomic hazards faced by rag pickers include walking long distances on foot, 6 often pulling heavy carts and in awkward positions as they collect and separate waste [7-10]

Biological hazards reported by rag pickers included bandages, disposable diapers, toilet paper, sanitary napkins, disposable needles or syringes, and condoms. In addition, wastes from small clinics, pharmacies, and labs, and even hospital wastes, may also be found mixed with residential trash and carrying microorganisms responsible for more serious diseases[7, 8].

Safety hazards include risks from working amid heavy traffic, as trash collection schedules often coincide with intense traffic hours. When combined with poor compliance with traffic laws, high workload, and fast pace of work, there is a substantial risk of rag pickers being hit by traffic. Some of the most common injuries to workers who handle solid wastes are cuts and punctures by glass, cans, and sharp objects. Many of these injuries are caused by inadequate storage of trash $[7,8]$.

In Mumbai, If Rag pickers don't spend their day sorting out and selling garbage, they can't eat. The women are 
anemic; their children are born underweight, and often don't survive beyond two months. Amongst those that do, their nutritional status keeps going down because they live only on breast milk. Children of rag pickers are not able to attend AWC leading to deprived nutritional status [12].

The work stresses that they face include: inherent dangers of their work sites (dumps, riverbanks, roadsides), their lack of personal protective equipment, the risk of traffic accidents because they often work amidst heavy traffic at intense traffic hours, irregular hours of work including at night, social isolation and discrimination by society, and considerable financial insecurity. It is reasonable to assume that all of these can have negative impacts on their mental health. The work of rag pickers involves frequent static postures, and this has been previously linked with musculoskeletal pain. The rag pickers work in hazardous conditions. When moving around in the garbage, searching for materials that can be resold, the rag pickers are exposed to a wide range of health and safety hazards; ranging from infectious agents and toxic chemicals, the handling of sharp or broken materials and serious musculoskeletal strain[7]. Female eve teasing is common among Rag-pickers. Very few female Rag-pickers are having separated married life from their husband. Female Rag-pickers who are having widow as status are found to be common.

Static posture \& heavy work in turn may lead to depression and anxiety. Monotonous work has been associated with psychological distress [9].

The rag pickers showed a higher prevalence of low hemoglobin, high circulating eosinophil and monocyte counts, unhealthy gums, frequent diarrhea, and dermatitis, when compared with controls. Their sputum showed an abundance of alveolar macrophages, siderophages and inflammatory cells, and a very high frequency of squamous metaplasia and dysplasia of bronchial epithelial cells, suggesting inflammation and cellular changes in the airways. Conclusion: The rag pickers suffer from a multitude of health problems which seem related to their occupation. [11].

Similar findings were observed from this study, which carried out in the slums of Mumbai.

\section{Conclusion}

The present study has attempted to explore the health status of rag pickers in the slum areas of Mumbai city. They develop bad habits of smoking, chewing pan, tobacco and gutaka and are also likely to be exposed to alcohol. Adverse work condition, poor nutrition, inability to practice personal hygiene measures were the contributory factors reflected in their morbidity profile of the rag pickers. The key determinants of health of participants were found which includes addiction, low knowledge about diseases spread due to handling of solid waste and personal hygiene practices, lower levels of health seeking behaviour etc. The physical and mental illnesses were found prevalent in the community of rag pickers which needs immediate attention at the level of corporations. The national programs such as National Urban Health Mission (NUHM) and National Urban Livelihood Mission (NULM), Jawarlal Nehru National Urban Renewal Mission (JnNURM) etc. needs to be strengthened and should be implemented effectively to cater to the poor people in the urban areas, focussing on providing health and other basic facilities to these communities.

\section{Recommendations}

\subsection{Short Term Recommendations}

(1) Local Municipal Corporations can organize health camps not only for treatment but also for scrutiny for various diseases.

(2) Counselling centre is also developed for Rag-pickers.

(3) At dumping ground toilet facilities should be provided for ladies.

(4) Drinking water and hygienic shelter (for eating food) should be there in dumping ground.

(5) In Rainey season foot wears, raincoat etc. should be provided to Rag-pickers.

(6) Legislation: to compulsory use of mask, protective cloths and gloves on working side.

(7) Local Municipal Corporation with the help of local NGO group can form "KACHARA KAMGAR Committee" so cases of local exploitation from police, kantewala, local gunda etc. will not happen.

(8) Vaccinate Rag-pickers with hepatitis A and B, Tetanus, and various other vaccines.

(9) Develop training materials on occupation and environmental health and injury issue relating to waste management.

(10) Strictly prohibition of domestic animal fed on chemical waste material.

(11) Self-help group like Mahila Mandal should be developed for understanding of various problem of female at working side.

\subsection{Long Term Recommendations}

(1) Self-help groups among rag-pickers can be formed for micro-finance under National Urban Livelihood Mission (NULM) and National Urban Health Mission (NUHM).

(2) Integrated approach towards waste management: IEC approach for households for recyclable material and their proper disposable so that Rag-pickers morbidity will decreases automatically and improve their life condition.

(3) Encouraging recycling: modern technology threatens work of rag-pickers and also increases pollution so for better environment we should encourage recycling, which also benefit for Rag-pickers and various stakeholder involved in it.

(4) Informal ways of education with the help of local NGO should be provided to those cannot attend school due to work. 


\section{References}

[1] Uplap P, Bhate K. Health profile of women ragpicker members of a nongovernmental organization in Mumbai, India. Indian J Occup Environtal Med. 2014; 18 (3): 140-4.

[2] Firdaus G, Ahmad A. Management of Urban Solid Waste Pollution in Developing Countries. Int J Environ Res. 2010; 4 (4): 795-806.

[3] Rao J, Shantaram V. Ground water pollution from Refuse Dumps at Hyderabad. Indian J Environ Health. 1995; 37 (3): 197-204.

[4] Devi KS, Swamy AVVS, Hema R. Studies on the Solid Waste Collection by Rag Pickers at Greater Hyderabad Municipal Corporation, India. 2014; 3 (1): 13-22.

[5] Da Silva M, Fassa A, Kriebel D. Minor psychiatric disorders among Brazilian ragpickers: a cross-sectional study. Environ Heal A Glob Access Sci Source [Internet]. 2006; 5 (1): 17. Available from: http://www.ehjournal.net/content/5/1/17.

[6] Mili D. Migration and healthcare: access to healthcare services by migrants settled in Shivaji Nagar Slum of Mumbai, India. theHealth. 2011; 2 (3): 82-5.
[7] Da Silva MC, Fassa a G, Siqueira CE, Kriebel D. World at work: Brazilian ragpickers. Occup Environ Med. 2005; 62: 736-40.

[8] Ferreira J a., Anjos L a. Public and occupational health issues related to municipal solid waste management. Cad Saude Publica. 2001; 17 (3): 689-96.

[9] Waxman R, Tennant A, Helliwell P. Community survey of factors associated with consultation for low back pain. Br Med J. 1994; 317: 1564-7.

[10] Nahit ES, Macfarlane GJ, Pritchard CM, Cherry NM, Silman a J. Short term influence of mechanical factors on regional musculoskeletal pain: a study of new workers from 12 occupational groups. Occup Environ Med. 2001; 58: 374-81.

[11] Ray MR, Mukherjee G, Roychowdhury S, Lahiri T. Respiratory and general health impairments of ragpickers in India: a study in Delhi. Int Arch Occup Environ Health [Internet]. 2004; 77 (8): 595-8. Available from: http://www.ncbi.nlm.nih.gov/pubmed/15538615.

[12] Bhavsar S, Hemant M, Kulkarni R. Maternal and Environmental Factors Affecting the Nutritional Status of Children in Mumbai Urban Slum. Int J Sci Res Publ. 2012; 2 (11): 1-9. 